\title{
HUBUNGAN DUKUNGAN SOSIAL ORANTUA DAN PERKEMBANGAN EMOSIONAL TERHADAP PROSES BERFIKIR ANAK AUTIS
}

\author{
Ike Peny Rendani \\ Pendidikan Luar Biasa, Fakultas Ilmu Pendidikan, Universitas Negeri Surabaya \\ ikepenyrendani16010044002@mhs.unesa.ac.id \\ Annisa Fatmawati, Danu Eka Meiputra \\ Pendidikan Luar Biasa, Fakultas Ilmu Pendidikan, Universitas Negeri Surabaya \\ annisafatmawati16010044031@mhs.unesa.ac.id, danu.1701004402.mhs.unesa.ac.id
}

\begin{abstract}
Abstrak
Dukungan sosial yang diberikan orangtua terhadap anak berkebutuhan khusus sangat diperlukan terutama anak dengan spektrum autis yang memiliki masalah berfikir, hal ini di manfaatkan untuk anak agar mampu berfikir dengan baik dengan menaikan minat anak terhadap hal-hal yang disukainya. Tujuan dari penelitihan ini mendeskripskian dukungan sosial orangtua dan perkembangan emosional terhadap proses berfikir anak autis. Metode penelitihan kualitif ini menggunakan metode observasi dan wawancara di SLB Autis Harapan Jaya Gresik, Hasil dukungan sosial yang diberikan orangtua berupa kasih sayang, arahan dan bimbingan akan cukup meminimalisir hambatan anak, termasuk emosional dan proses berfikirnya.
\end{abstract}

Kata kunci: Perkembangan Emosional, Dukungan Sosial, Proses Berfikir, Autis

\begin{abstract}
Social support provided by parents to children with special needs is very much needed, especially children with the autistic spectrum who have thinking problems, this is used for children to be able to think well by increasing children's interest in the things they like. The purpose of this study is to describe parental social support and emotional development of the thinking process of autistic children. This qualitative research method uses observation and interviews at SLB Autism Harapan Jaya Gresik. The results of social support provided by parents in the form of love, direction and guidance will be sufficient to minimize children's barriers, including emotional and thought processes.
\end{abstract}

Keywords: Emotional Development, Social Support, Thinking Process, Autism

\section{PENDAHULUAN}

Usaha yang dilakukan oleh manusia secara sadar dan juga terencana serta terarah untuk megembangkan potensi dalam diri tiap tiap individu dalamn aspek spriritual, pengendalian diri, kepribadian, kecerdasan, akhlak mulia sera keterampilan dirinya, masyarakat, bangsa dan negara disebut dengan pendidikan dalam UU No. 20 tahun 2003. Sudah menjadi rahasia umum setiap manusia sangat memerlukan pendidikan untuk mengembanhkan potensi bawaan yang dimiliki sejak lahir. 
Pendidikan untuk era sekarang ini tidak hanya bagi mereka yang normal tapi juga bagi mereka yang berkbutuhan khusus, sebab dengan pendidikan mampu memupuk dan mengaraahkan proses berfikir dalam tiap-tiap diri Individu. Proses berfikir seorang anak tidak hanya terpatok pada perkembangan intelegensinya, tapi hal paling penting adalah pengaruh dari adanya dukungan dari orangtua.

Dukungan sosial menurut Sarafino (1994) memiliki peran yang penting bagi tiap tiap individu yang ada pada tahap perkembangan, bantuan yang diterima individu dari orang lain atau kelompok di sekitarnya, sehingga rasa nyaman, dicintai dan dihargai adapat dirasakan oleh individu disebut dengan dukungan sosial. Dukungan sosial yang diberikan orangtua terhadap anak terkhusus anak berkebutuhan khusus sangat diperlukan, hal ini di manfaatnya adalah untuk menaikan minat anak terhadap hal-hal yang dilakukannyua.

Kondisi individiu yang mengalami hambatan secara kompleks dalam diirnya, dan berkenaan pada sistem nenurologisnya kerap disebut dengan Autism. Senada dengan apa yang dikatan oleh Yuwono (2009:26) bahwa autism mengalami masalah dalam neurobiologisnya yang sangat kompleks/berat dan panjang meliputi gangguan ingtelegensi, komunikasi, dan perilaku serta pada spek sensori motorisnya. Anak dengan hambatan ini mengalami tingkat emosi yang berlebih sehingga mengakibatkan terhambatnya proses berfikirnya anak .

Emosi mampu mendorong individu terhadap sesuatu, missal emosi gembira mendorong untuk tertawa, atau dengan perkataan lain emosi didefinisikan sebagai suatu keadaan gejolak penyesuaian diri yang berasal dari dalam dan melibatkan hampir keseluruhan diri individu (Sujiono, 2005). Goleman (2003) mengatakan bahwa pentingnya keterampilan emosional diberikan dalam proses pembelajaran anak karena hal ini dapat memperbaiki nilai prestasi akademis dan kinerja sekolah anak.

Berdasar hal diatas dapat digabung dan diambil kesimpulan bahwa anak dengan hambatan autis memiliki emosional yang tidak terkendali dan dukungan sosial terutama dari orangtua kalah yang dibutuhkan anak untuk mampu berproses berfikir dengan baik.

\section{METODE}

Dalam penelitihan ini menggunakan metode kualitatif yang dapat diperoleh dari sumber data langsung dengan mementingkan proses daripada hasil. Metode Kualitatif menafsirkan interaski perilaku manusia dengan peristiwa yang ditinjau dari pendapat peneliti sendiri dan berdasar kajian pustaka yang ada. Hasil penelitian berupa laporan verbal yang datanya didapatkan peneliti melalui serangkaian observasi atau pengamatan dan juga wawancara dengan berbagai objek subjek terkait. Penelitian dilakukan di SLB (Sekolah Luar Biasa) Autis Harapan Bangsa, di Puri Amerta Regency, 
No.12, Gresik. SLB Harapan Bangsa memiliki murid sebanyak 14 oramng siswa, dengan rata-rata memiliki hambatan autis. SLB Harapan bangsa telah meluluskan sedikitnya 2 orang siswanya di jenjang SMP (Sekolah Mennegah Pertama) . Tahapan dalam penelitian ini ada beberapa 1) Pengumpulan data , 2) Pengurangan data , 3) Penyajian data 4) Kesimpulan.

- Tahap Pengumpulan Data

Pengumpulan data dari berbagai sumber baik primer maupun sekunder sebagai bahan untuk mendukung penelitian. Teknik pengumpulan data dilakukan dengan cara pengamatan lingkungan dan juga wawancara dengan subjek objek terkait

- Tahap Pengurangan Data / Reduksi Data

Reduksi data merupakan pemilihan atu penyaringan dari berbagai sumber data yang telah terkumpul secara langsung. Data akan dipilih dan disesuaikan secara struktural selama proses penelitian. Peneliti akan mengklasifikasi data untuk disesuaikan dengan tujuan penelitian. Reduksi data akan memudahkan peneliti untuk fokus terhadap penelitian sehingga terus berlanjut sampai akhir laporan penelitian.

- Tahap Penyajian Data

Proses penyajian data ini serangkaian dari hasil reduksi data yang menyajikan gambaran dari informasi yang diperoleh secara langsung. Peneliti akan menyajikan data secara mendalam dan relevan dengan menganalisis data yang telah diperoleh.

- Tahap Kesimpulan

Dari hasil data yang telah diperoleh maka peneliti akan menarik kesimpulan berdasarkan hasil pengumpulan data dan teori-teori untuk mengetahui sebab akibat dari rumusan permasalahan yang ada sehingga diperoleh informasi dan data yang valid berdasarkan penganalisisan yang dilakukan oleh peneliti.

\section{HASIL DAN PEMBAHASAN}

\section{Hasil}

Hasil penelitian yang dihasilkan penelitain ini merupakan kutipan wawancara dengan para walimurid maupun guru anak dengan hambatan autis di tempat penlitian

\section{A. Observasi}

Pengamatan dilakukan di salah satu Sekolah Luar Biasa (SLB Autis) Harapan Bangsa yang terletak di Puri Amerta Regency, Randegansari, Gresik. Observasi yang dilakukan melibatkan semua anggota tim peneliti. 
1. Tingkat emosional siswa

Siswa yang berada di sekolah ini mayoritas memiliki respon yang sangat positif terhadap orang-orang baru. Guru yang berada di SLB Autis Harapan Bangsa pun memiliki andil penting rupanya dalam perkembangan emosional siswa, terkadang guru tak segan untuk memancing respon siswa menggunakan cara-cara yang unik . Misalnya, ketika ada siswa yang bermain bola saat pelajaran berlangsung, guru akan mengambil bola lalu menyembunyikannya. Siswa yang terlihat akan marah dan berteriak sesegera mungkin ditenangkan "sabar sabar " kata guru nya. Dan begitu siswa akan mengerjakan tugas yang belum selesai kemudian setelah tugas selesai, guru akan mengembalikan bola tersebut. Hal ini dikatakan guru sebagai sebjuat " Reward “

2. Interaksi Sosial

Siswa SLB Autis Harapan Bangsa, memiliki kemampuan interaksi sosial yang cukup baik. Anak-anak memilki respon yang sangat positif jika bertemu dengan orang baru, namun ada beberapa siswa yang memiliki permasalahan dalam perilakuya secara berat sehingga tidak dapat merespon interaksi disekitarnya dengan baik. Interaksi antar sesama siswa cukup baik, terkadang emosi beberapa anak masih sanagt sulit untuk dikondisikan, misalnya ketika waktu istirahat, semua siswa sedang makan namun ada satu anak yang tiba-tiba mengambil minuman salah satu siswa yang sedang makan, lalu siswa yang sedang makan pun marah dan berteriak-teriak. Namun, jika kondisi seperti maka guru akan melerai keduanya dan berakhir dengan saling meminta maaf dan berjabat tangan.

3. Proses Berfikir

Siswa SLB Autis Harapan Bangsa, memiliki proses berfikir yang berbeda-beda, hanya beberapa siswa yang mampu berfikir dengan baik atau yang mampu memahami setidaknya 1 kali intruksi dengan 3 aktivitas didalamnya. Siswa yang sudah mampu berpikr dan menerima instruksi dengan baik rata-rata memiliki tingkat emosional yang dapat dikendalikan, seperti ketika memiliki makanana ia akan berbagi dengan temannya.

4. Kontribusi di Dalam Kelas

Siswa di SLB Autis Harapan Bangsa, saat pembelajaran berlangsung memiliki kebiasaan sendiri-sendiri, terkadang ada yang sangat amat aktif namun juga ada yang sangat amat pasif , hal ini disebabkan oleh beberapa hal yang melatarbelakangi adanya masalah ini yakni kondisi siswa ketika berangkat sekolah, beberapa siswa terlihat memiliki suasana hati yang jelek, maka ketika pembelajaran berlangsung ia juga akan sangat susah untuk mengikuti. Begitupun sebaliknya, ketika kondisi siswa baik saat akan berangkat sekolah maka ia akan sangat mudah aktif dalam pembelajaran 


\section{B. Wawancara}

Metode pengumpulan data yang kami lakukan selain observasi adalah wawancara, subjek dalam wawancara adalah para orang-orang yang berada di lingkup dekat anak, yakni orangtua dan guru kelas.

\section{Orangtua Siswa}

1. Ibu Rahayu (Wali Murid dari Cinta)

Bagaimana respon orangtua ketika mengetahui kondisi anak yang memiliki kebutuhan khusus?

Tentu saat itu saya sangat terpukul, sebab cinta adalah anak pertama dan tunggal. Saya menunggu kehamilan selama 7 tahun setelah menikah, saat kehamilan tidak ada yang ganjal, semuanya normal saja mbak. Tapi saat usia kehamilan 8 bulan, saya sempat mengalami demam tinggi. Saat itu langsung operasi Caesar, dia lahir dengan sangat kecil, bobotnya hanya $1 \mathrm{~kg}$, saat umur 3,5 tahun di beri tahu oleh dokter jika Cinta mengalami hambatan autis cerebral palsy. Sempat frustasi, tapi kembali lagi bahwa saya yang minta Allah berikan keturunan jika memang ini yang diberi Allah tentu saya harus bersyukur.

Usaha apa saja yang telah dilakukan orangtua untuk meminimalisir permasalahan dalam diri anak ?

Jika usaha sudah banyak sekali mbak, dari terapi sampai ke pengobatan natural, karena sangat ingin Cinta bisa seperti anak normal lainnya . Tapi tidak ada hasilnya, hanya saja saya dan suami tidak pernah mengeluh dan selalu beriktiar sampai menemukan SLB ini, di SLB ini juga menyediakan terapi jadi sekalian saja begitu, dan alhamdulilah Cinta sekarang sudah bisa berjalan, bubling dan juga sedikit memiliki kemandirian.

Apakah perilaku anak sering menunjukkan perilaku meminta perhatian lebih saat dirumah?

Sering sih mbak, seperti merancau ketika dia lapar, dan juga menjatuhkan barang didekatnya jika saya meninggalkannya lama .

\section{Apakah anak sering melakukan tindakan Agresif ketika dirumah ?}

Agresif mungkin ketika saya tidak memberikan apa yang dia mau, ia akan marah dengan menjatuhkan semua benda yang ada disekitarnya. Ia akan berdiri dan menjatuhkan benda lagi, dan lagi. Ia tidak akan mendengarkan perkataan saya atau suami. Hingga saya memberikan apa yang ia mau, baru Ia akan diam dan duduk.

\section{Bagaimana perkembangan proses berfikir anak menurut orangtua?}

Berfikir Cinta itu lama mbak, kan mungkin karena dia $C P$ dan juga autis ya, jadi jika memberi instruksi harus berkali-kali, Cinta akan menuruti hal terssebut jika memang mudah 
ia kerjakan tapi jika sulit maka kami selaku orangtua akan memberika prompt atau berupa bantuan untuknya .

\section{Apa bentuk dukungan sosial yang telah dilakukan oleh orangtua ?}

Bentuk dukungannya ya mungkin dengan memberikan Prompt saat Ia tidak dapat melakukan nya dengan sendiri, dengan begitu maka ia merasa bahwa oh ini orangtua saya membantu, besok saya lakukan sendiri, terus dengan menyekolahkan cinta. Banyak mbak dukungannya.;

2. Ibu Peny (Orangtua Rauuf)

Bagaimana respon orangtua ketika mengetahui kondisi anak yang memiliki kebutuhan khusus?

Raauf anak saya, did diagnosa oleh dokter dan psikolog, mengalami Autis Hiperaktif, saya sangat sedih sebab Raauf adalah anak pertama saya, namun suami tidak merasa sedih sedikitpun, ia menguatkan saya. Meyakinkan hal terindah ini adalah kuasa Tuhan.

Usaha apa saja yang telah dilakukan orangtua untuk meminimalisir permasalahan dalam diri anak ?

Usaha sudah banyak dilakukan, dari membawa terapi dan juga ke dokter spesialis anak, menjaga pola makan nya, menggunakan barang-barang memasak yang memang baik untuk nya.

Apakah perilaku anak sering menunjukkan perilaku meminta perhatian lebih saat dirumah ?

Tidak, Rauuf cenderung pendiam dan tidak ingin merespon lingkungannya . Bahkan untuk makanpun jika kami, orangtua tidak memaksanya ia tidak mau makan.

Apakah anak sering melakukan tindakan Agresif ketika dirumah ?

Ia punya adik, mungkin terkadang suka berebut mainan namun ketika saya memberitahu Ia dengan pelan bahwa perilaku itu jelek, Ia akan mengembalikan mainan kepada adiknya.

\section{Bagaimana perkembangan proses berfikir anak menurut orangtua?}

Umurnya masih sangat dini, masih belum bisa membedakan mana yang baik dan mana yang buruk, namun untuk memahami perintah sederhana Ia bisa, seperti " duduk " “ berhenti ", hanya saja kita sebagai orangtua harus benar-benar ngarahin aja .

Apa bentuk dukungan sosial yang telah dilakukan oleh orangtua?

Kami melakukan apapun demi anak kami, mengupayakan yang terbaik, kami menjaga anak kami untuk tidak mengkonsumsi makanan dengan bahan tambahan banyak sekali sebab jika tidak dijaga maka Ia akan sulit diarahkan untuk perilakunya, kami mengupayakan program terapi dirumah dan disekolah juga . 
3. Pak Andi ( Guru, SLB Harapan Bangsa )

Apa permasalahan yang signifikan terjadi pada anak dengan hambatan autis ?

Sangat kompleks ya mas, banyak aspek yang memiliki hambatan baik dari segi komunikasi, interaksi dan juga inteleknya.

\section{Bagaimana dengan Emosional anak dengan hambatan autis?}

Mereka memiliki tingkat emosi yang tinggi, perubahan suasana hati yang cepat, kadang bisa sedih tapi tiba-tiba marah dan membenturkan kepala ke meja tapi kadang juga bisa tertawa cekikikan. Emosionalnya maish sulit ditebak.

\section{Bagaimana dengan proses berfikir anak dengan hambatan autis ?}

Proses berfikir anak autis itu unik, terkadang kita menginstruksikan " ayo duduk " tapi mereka tidak menghiarukan, malah lari sana sini kemudian mereka akan duduk dengan sendirinya. Proses berfikir anak dengan hambatan autis itu kadang cenderung lambat tapi jika terus di asah, dilatih maka proses berfikir mereka akan tangkap.

\section{Bagaimana hubungan dukungan sosial orangtua terhadap proses berpikr anak dengan hambatan autis?}

Hubungan nya tentu sangat erat dan mempengaruhi sekali seperti yang sudah saya jawab sebelumnya bawa emosional anak dengan hambatan autis itu beragam, begitupun pula proses berfikirnya. Dukungan yang diberikan oleh orangtua itulah yang paling penting. Kenapa ? sebab orangtua yang berhubungan langsung dengan anak, yang mengtahui kebiasaan anak.

\section{Bagaimana hubungan emosional anak autis terhadap proses berfikirnya?}

Ada ahli mengatakan bahwa emosi seseorang emnjadi penentu perilakunya . Dan saya rasa ini juga berlaku untuk anak dengan hambatan autis, semakin emosi anak tidak terarah maka Ia akan sulit juga untuk menerima informasi, sulit diarahkan . Contohnya murid sini itu, Hanif. Emosionalnya sangat amat labil dan ini mempengaruhi proses berfikirnya. Sulit menerima arahan dan menerima bimbingan.

\section{Kesimpulan hasil observasi}

Bahwa anak autis memiliki masalah yang snagat kompleks pada pengembangannya , aspek -aspek yang cukup pemnting juga tidak terhindarkan untuk mengalami hambatan, seperti bahasa, interaksi sosialnya, proses berfikir, dan perilakunya. Emosionalnya anak dengan hambatan autis tidak dapat dikontrol ataupun ditebak, emosi yang terus melunjak dan tidak terarah jika tidak mendapat penanganan dan juga penguatan maka akan semakin mempengaruhi perkembangan anak termasuk juga proses berfikirnya. 
Dukungan sosial yang diberikan orangtua berupa kasih sayang, arahan dan bimbingan akan cukup meminimalisir hambatan anak, termasuk emosional dan proses berfikirnya .

\section{Pembahasan}

\section{A. Pengertian Anak dengan Hambatan Autis}

Kondisi individu yang mengalami permasalahan dalam perkembanganya , meliputi aspek komunikasi , interaksi sosial dan juga intelegensi bisa disebut dengan hambatan Autis. Senada dengan pemikiran para ahli bahwa kondisi autis terjadi sebab faktor genetik dan lingkungan (Peeters, 2004) Kondisi diri individu yang mengalami permasalahan dalam perkembangan neurobiologisnya dapat disebut dengan autism, gangguan autism ini menghambat dalam proses komunikasi, interaksi sosial, dan juga beberapa aspek penting lainnya seperti yang telah di paarkan oleh (WHO 2013). Dalam America Pscyantric Association : Diagnosis and Statistical Manual of Mental Disorder Fifth Edition (DSM-V) bahwa ganguan Autism Spectrum Disorder(ASD) mempengaruhi perkembangan saraf (neurodevelopmental disorder) dimana gangguan ditandai dengan adanya hambatan dalam sistem komunikasi dan interaksi sosial baik perilaku verbal dan nonverbal, penyimpangan pola perilaku, minat yang terbatas serta munculnya perilaku berulang atau yang kerap disebut dengan perilaku repetitif. Dalam buku yang ditulis oleh Hallahan dan Kaufman, 2011 mengutip dari The Individuals with Disabilities Education Act (IDEA) USA mengatakan bahwa gangguan yang dialami oleh autism akan mempengaruhi perkembangan interaksi sosial dan komunikasi verbal maupun nonverbal secara signifikan.

Gejala anak mengalami hambatan autis tertdiri darei tiga poin poenting yaitu, Anak dengan hambatan autis memiliki tingkat berfikir yang berbeda masing-masing anak, salah satu jurnal yang dikeluarkan oleh universitas Florida, 4 Januari 2008 " anak dengan hambatan autis memiliki bakat memori visual yang sangat baik, dan memiliki kemampuan berfikir menggunakan gambar secara baik pula. Dari pendapat diatas dapat dikatakan bahwa anak dengan hambatan autism lebih paham dengan bahasa visual daripada bahasa yang menggunakan banyak kata atau pengertian.

Dari beberapa hal diatas dapat diambil kesimpulan bahwa anak dengan autisme mengalami permasalahan yang kompleks, yakni di aspek komunikasi, interaksi sosial dan intelegensi. Hal yang diperlukan oleh anak adalah dukungan serta penguatan yang mampu ,menjadi sebuah reward tersendiri bagi anak.

\section{B. Emosional Anak dengan Hambatan Autis}

Reaksi individu terhadap bagaimana suatu hal itu terjadi atau terhadap kenyataan yang terjadi, baik respon positif maupun respon negatif dapat dinamakan dengan emosi. Setiap 
makhluk ciptaan Tuhan pasti memiliki emosi, tak terkecuali anak-anak dengan hambatan khusus , termasuk anak dengan hambatan autis yang memang terkenal dengan perubahan emosi yang tidak terkendali. Emosi sendiri memiliki manfaat yang beragam dalam diri individu, misalnya untuk memacu minat dan daya tarik. Daniel Goleman pada tahun 2000 mengatakan bahwa pergolakan pikiran, perasaan dan nafsu dalam diri Individu disebut dengan emosi. hal ini diperkuat dengan pendefinisian emosi oileh Lzzarus (1991) bahwa emosi mampu mendorong suatu perubahan dalam diri Individu. Dapat ditarik kesimpulan bahwa emosi merupakan suatu wujud adanya pergolakan pikiran, dan perasaan .

Emosional anak dengan hambatan autis pun tidak jauh berbeda, anak dengan hambatan autis memiliki emosi yang sama dengfan anak normal, mereka dapat merasakan sedih, marah, bahagia, dan juga kesakitan. Emosi anak dengan hambatan autis masih sering berubah-ubah dan tidak dapaty konsisten walau dalam hitungan dtik. Hal inilah yang menjadi pemicu untama terganggunya proses berfikir nya.

Anak dengan hambatan autis akan mudah marah saat suatu hal yang ia miliki atau inginkan direbut atau hilang dari jangkaunnya, biasanya kondisi anak autis dengan emosi berlebih dan tidak terkontrol ini dapat dikatakan dengan Tantrum atau emosi yang tidak terkendali. Saat emosi anak memuncah, anak tidak akan mampu untuk memproses informasi.

Informasi dari lingkungan yang disampaikan pada anak dengan hambatan autis ketika emosi anak tidak dapat terkendali merupakan tindakan yang salah, sebab ketika emosi anak memuncah, kinerja otak anak hanya akan tergfokus pada apa yang ia inginkan, apa yang ia cari dan apa yang ia mau. pemberian intruksi yang berlebih pada saat konsdisi anak seperti ini justru akan membuat anak semakin terdistraksi jauh dan membuat anak akan sulit dikendalikan.

Pengendalian emosi anak sangat diperlukan untuk dapat mendapuk anak memiliki perilaku dan tingkat emosi yang normal dan stabil. Emosi yang stabil akan mempengaruhi sitem berfikir anak, sebab informasi yang diterima dengan kondisi baik akan cepat mudah di pahami oleh anak, hal ini dibuktikan dengan pengamatan yang telah dilakukan oleh tim peneliti selaman beberapa bulan hingga menghasilkan hal yang konsisten.

\section{Proses Berfikir anak Autis}

Dari beberapa penjabaran diatas, sudah dapat ditemukan titik terangnya bahwa proses berfikir anak dengan hambatan autis sebagai berikut:

- Tak ada penyembuh yang pasti bagi autisme. Treatmen yang biasa dilakukan diantaranya berupa dietary modification (gluten-free, casein-free diets), secretin (hormon yang dapat mengontrol sistem pencernaan), auditory training, sensory integration dan latihan komunikasi yang terfasilitasi. 
- Treatmen ditujukan pada bagaimana memaksimalkan potensi anak (improve learning and behavior, achieve near-normal functioning), serta membantu anak dan keluarganya agar memiliki kemampuan coping yang lebih efektif dalam menghadapi gejala-gejala autis ini.

- Treatmen yang paling efektif yakni menggunakan strategi skill-oriented terstruktur yang diberlakukan pada si anak (contoh: Language fluency, interaksi sosial yang sesuai dengan usia anak, mengajarkan perilaku dan ketrampilan apa yang sesuai ditampilkan di dalam kelas), serta menyediakan sarana edukasi dan supportif konseling bagi keluarga.

- Keberhasilan treatmen turut dipengaruhi oleh berat/ringannya simtom, derajat gangguan bahasa, level intellectual-functioning, serta kapan dimulainya pemberian treatmen. Anak autis yang ditangani secara lebih dini cenderung menunjukkan hasil yang lebih baik.

- Penyandang autis yang memiliki kesempatan terdiagnosis lebih awal memungkinkan tatalaksana yang lebih dini dengan hasil yang lebih baik. Deteksi dini sangat penting dan berpengaruh terhadap prognosis penyandang. Upaya deteksi dini yang optimal diperlukan kerjasama peranan orang dan dokter baik dokter umum atau dokter anak dalam melakukan skrening terhadap penyandang yang dicurigai autis.

\section{PENUTUP}

\section{Simpulan}

Bahwa anak autis memiliki masalah yang sangat kompleks pada pengembangannya, aspekaspek yang cukup penting juga tidak terhindarkan untuk mengalami hambatan, seperti bahasa, interaksi sosialnya, proses berfikir, dan perilakunya. Emosionalnya anak dengan hambatan autis tidak dapat dikontrol ataupun ditebak, emosi yang terus melunjak dan tidak terarah jika tidak mendapat penanganan dan juga penguatan maka akan semakin mempengaruhi perkembangan anak termasuk juga proses berfikirnya.

Dukungan sosial yang diberikan orangtua berupa kasih sayang, arahan dan bimbingan akan cukup meminimalisir hambatan anak, termasuk emosional dan proses berfikirnya. Proses berfikir yang dimaksud disini adalah saat anak dapat menerima pelajaran dengan mudah atau malah sebaliknya.

\section{Saran}

Treatmen yang paling efektif yakni menggunakan strategi skill-oriented terstruktur yang diberlakukan pada si anak (contoh: Language fluency, interaksi sosial yang sesuai dengan usia anak, mengajarkan perilaku dan ketrampilan apa yang sesuai ditampilkan di dalam kelas), serta menyediakan sarana edukasi dan supportif konseling bagi keluarga. Penyandang autis yang memiliki kesempatan terdiagnosis lebih awal memungkinkan tatalaksana yang lebih dini dengan 
hasil yang lebih baik. Deteksi dini sangat penting dan berpengaruh terhadap prognosis penyandang. Upaya deteksi dini yang optimal diperlukan kerjasama peranan orang dan dokter baik dokter umum atau dokter anak dalam melakukan skrening terhadap penyandang yang dicurigai autis.

\section{DAFTAR PUSTAKA}

Azwar, Saifudin. 2003. Metode Penelitian. Yogyakarta: Pustaka Pelajar.

Ellah Siti Chalidah. 2005. Terapi permainan bagi anak yang memerlukan layanan pendidikan khusus, Sumber: Dikdasmen Depdiknas

Darmadi, Kaswan. 1996. Meningkatkan Kemampuan Menulis Panduan untuk Mahasiswa dan Calon Mahasiswa.Yogyakarta: ANDI Yogyakarta

Goleman, Daniel. 2003. Emotional Intelligence. Jakarta: PT Gramedia Pustaka Utama

Hallahan, Daniel P. and Kauffman, James M. 2011. Handbook of Special. Education. New York : Routledge Taylor and Francis Group

Lazarus, R. S. 1991. Emotion and adaptation. Oxford University Press.

Lutthfiyah dan Fitrah Muh. 2017. Metodologi Penelitian; Penelitian Kualitatif, Tindakan Kelas \& Studi Kasus. Sukabumi: Jejak Publisher

Peeters, Theo. 2004. Autisme : Hubungan Pengetahuan Teoritis dan Intervensi Pendidikan Bagi Penyandang Autis. Jakarta : PT. Dian Rakyat

Sarafino. 1994. Health Psychology Biopsychosocial Interaction. USA : John Wiley \& Sons

Sujiono,Bambang Dan Yuliani Nurani Sujiono. 2005. Menu Pembelajaran Anak Usia Dini. Jakarta: Yayasan Citra Pendidikan Indonesia

Yuwono, J. 2009. Memahami Anak Autistik. Bandung: CV Alfabet 